\title{
RESEARCH ON DETOXICATION OF SOILS POLLUTED WITH ARSENIUM AND DEVELOPMENT OF NEW SORBING MATERIALS
}

\author{
L.V. Kireycheva, L.I. Moskovkina \\ All-Russian Research Institute for Hydraulic Engineering and Reclamation, \\ 44 Bolshaya Academicheskaya street, Moscow, Russia
}

Arsenium being a hazardous substance is harmful for plants, animals and humans. Having been applied to the soil arsenium is partly transformed as the result of interaction with the soil minerals. It may enter plants, animals as well as human body through the feed circuit. Nowadays issue of the anthropogenic impact diminishing as well as environmentally friendly farm production obtaining in the polluted soils becomes more and more urgent. Therefore development of soil detoxication techniques using natural sorbing materials is challenging and timely.

On the base of the previous research analysis and references natural sorbing materials (such as sapropel, vermiculite, diatomite, zeolite, kaolinite clays, peat) were selected to adsorb mobile arsenic [1]. To estimate sorbing materials efficiency simulated experiment was carried out. Sorbing materials were applied into the preliminary polluted (using $\mathrm{Na}_{2} \mathrm{AsO}_{3}$ ) soil at the application rate of $1 \mathrm{~kg} / \mathrm{m}^{2}$, after solution stabilization soil arsenic content was estimated using Spectroscan. The sorption capacity range was determined for the different sorbing materials as the result of the experiment (Figure 1)

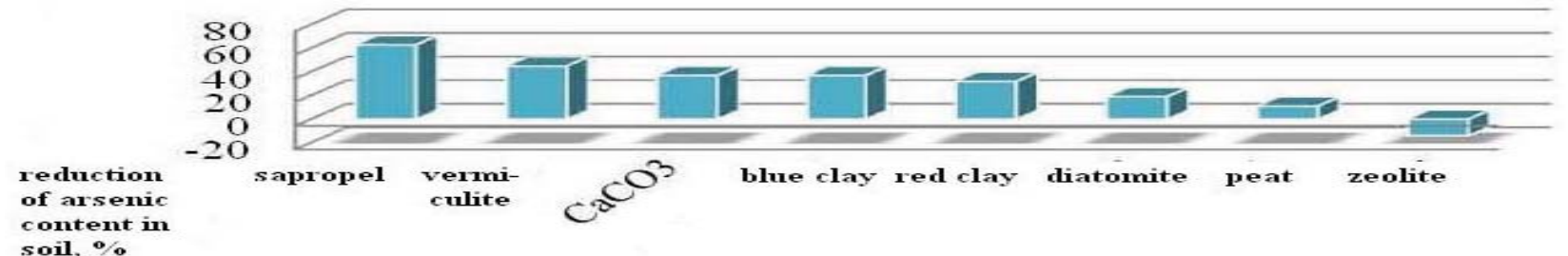

Figure 1 - Sorption capacity range for different sorbing materials at arsenic sorption in soils.

At the next stage of the research mixtures of different sorbing materials were made and tested during experiment. To improve sorption capacity some natural sorbing materials were treated with ferric iron. Vermiculite and diatomite mainly being comprised of silicon oxide (30\% and $90 \%$ correspondently) and due to their porous structure were treated with ferric iron. This porous structure is a basic for ferric iron settling without its chemical linkage which provides high sorption capacity of pretreated sorbents in soils.

Sapropel and peat are treated with ferric iron too. The range of sorption capacity of sorbing materials mixtures and their pretreated modifications are shown on the Figure 2.

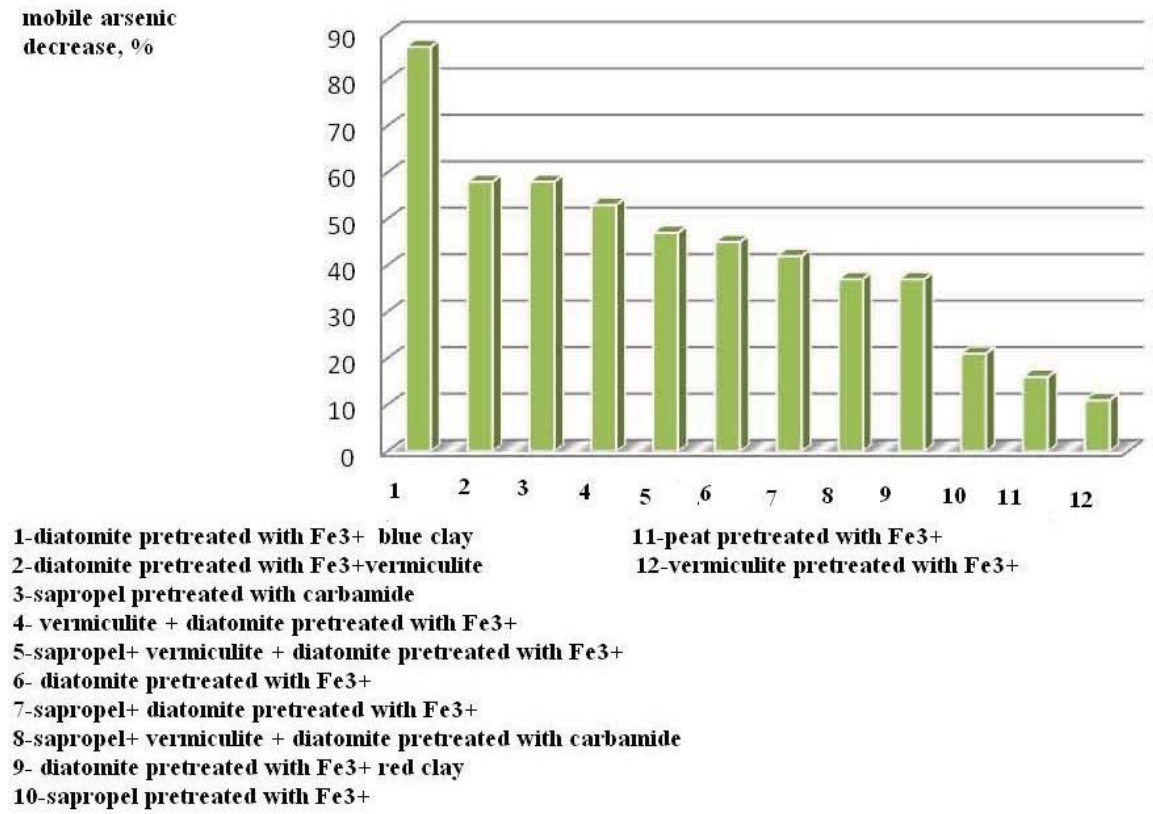

Figure 2 - The range of sorption capacity of sorbing materials mixtures and their pretreated modifications. 
Mixture of diatomite pretreated with $\mathrm{Fe}^{3+}$ and blue clay having been applied into soil showed the best efficiency at mobile arsenic sorption (87\%). As the result of the experiment the following mixtures were selected for the further research: mixture $\mathrm{N} 1$ (diatomite pretreated with $\mathrm{Fe}^{3+}$ and blue clay) and mixture $\mathrm{N} 2$ (sapropel pretreated with $\mathrm{CaCO}_{3}$ ) $[2]$.

To investigate natural sorbing materials influence on the arsenic accumulation in the crops plant experiment was carried out. Crops (garden radishes, oat and wheat) were planted in soil polluted with arsenic at the application rates 20,40 and $80 \mathrm{mg} / \mathrm{kg}$, as well as in soil without arcenic application [3].

Mixture N1 provided high efficiency at detoxication of soil polluted with arsenic. Standard crops (oat, spring wheat, garden radishes, lettuce) were obtained in polluted soils in the case of corresponding application rates of sorbing materials and their mixtures (Figure 3).

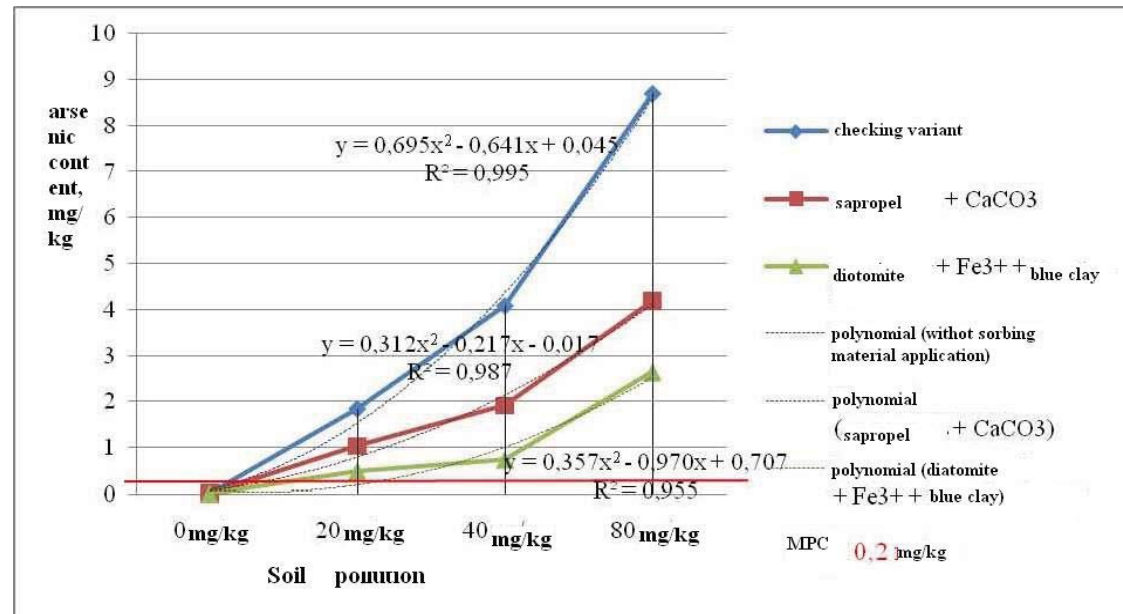

Figure 3 - Arsenic content in lettuce.

Lysimeter experiment was carried out to confirm high efficiency of mixtures N1 and N2. There were the following variants of the lysimeter experiment:

- checking (soil without arsenic pollution),

- arsenic content in soil - $40 \mathrm{mg} / \mathrm{kg}$ - without sorbing materials application;

- arsenic content in soil - $40 \mathrm{mg} / \mathrm{kg}+$ mixture №1 $\left(1 \mathrm{~kg} / \mathrm{m}^{2}\right)$,

- arsenic content in soil - $40 \mathrm{mg} / \mathrm{kg}+$ mixture №2 $\left(1 \mathrm{~kg} / \mathrm{m}^{2}\right)$.

As the result of arsenic toxicity wheat productivity is reduced by $24 \%$ as compared to the checking variant in the first year of the lysimeter experiment. For the second year of the lysimeter experiment wheat productivity was higher by $24 \%$ in the variant with polluted soil as compared to the checking variant (Figure 3 ). As the result of self-purification capacity of the polluted soil arsenic content was reduced and it transferred into the useful microelement- phosphorus analog. However arsenic content in grain crop exceeded maximum permissible concentration. In the variant of diatomite pretreated with $\mathrm{Fe}^{3+}+$ blue clay application excess of $\mathrm{Fe}$ in soil causes wheat productivity reduction by $28 \%$ as compared to the checking variant for the first year of the lysimeter experiment, wheat productivity being increased by $43 \%$ during the second year of the experiment. For the variant of sapropel $+\mathrm{CaCO}_{3}$ application wheat productivity was increased by $51 \%$ as compared to the checking variant due to the fertilizing value of sapropel.

For the variant of diatomite pretreated with $\mathrm{Fe}^{3+}+$ blue clay application arsenic content in grain crop was decreased up to $0-0,01 \mathrm{mg} / \mathrm{kg}$ (table 1 ). Arsenic content was reduced in roots-by $61 \%$; in stalks - by $50 \%$; for the plant in average -in 7 times (as compared to the variant of arsenic content in soil $-40 \mathrm{mg} / \mathrm{kg}$-without sorbing materials application) (2011 data). For the variant sapropel $+\mathrm{CaCO}_{3}$ arsenic content was decreased in grain crop - by $67-75$; in stalks - by $73 \%$; in roots-by $46 \%$. Arsenic content in grain crop did not exceed maximum permissible concentration for above mentioned two sorbing materials application.

Nitrogen and protein content in wheat grain was higher for the variant of diatomite pretreated with $\mathrm{Fe}^{3+}+\mathrm{blue}_{\mathrm{u}}$ clay application as compared to the checking variant due to the fertilizing value of sorbing materials. It's important that quality of crops met the requirements of a standard good for the variant of diatomite pretreated with $\mathrm{Fe}^{3+}+$ blue clay application and it was not deteriorated for other sorbing materials application.

To estimate efficiency of mixture N1 (diatomite pretreated with $\mathrm{Fe}^{3+}+$ blue clay) at its application in locally polluted soils field experiment was carried out near the town Skopino in the Riazan region. Arsenic content in soil within the experimental plot was $54,45 \mathrm{mg} / \mathrm{kg}$. Spring oat was planted. Sorbing material was applied at the rate of $10 \mathrm{t} / \mathrm{hectare}$. Application plots' area was $2 \mathrm{~m}^{2}$, shelter belt width was $1 \mathrm{~m}$, replication -3 times. 
A) in 2010 .

\begin{tabular}{|l|c|c|c|}
\hline \multicolumn{1}{|c|}{ Variant of the experiment } & $\begin{array}{c}\text { Arsenic content in } \\
\text { roots, } \mathbf{~ m g / k g}\end{array}$ & $\begin{array}{c}\text { Arsenic content in } \\
\text { stalks, } \mathbf{~ m g} / \mathbf{k g}\end{array}$ & $\begin{array}{c}\text { Arsenic content in } \\
\text { grain, } \mathbf{~ m g / k g}\end{array}$ \\
\hline $40 \mathrm{mg} / \mathrm{kg}$ & 19,6 & 2,6 & 0,4 \\
\hline $40 \mathrm{mg} / \mathrm{kg}+$ diatomite pretreated with & 7,7 & 1,3 & $-*$ \\
$\mathrm{Fe}^{3+}+\mathrm{blue}$ clay & & 0,7 & 0,1 \\
\hline $40 \mathrm{mg} / \mathrm{kg}+$ sapropel $+\mathrm{CaCO}_{3}$ & 10,5 & 0,35 & 0,05 \\
\hline $\mathrm{HCP}_{05}$ & 2,43 & & \\
\hline
\end{tabular}

Note $-*$ arsenic was not determined by atomic absorptive analyzer

Б) in 2011.

\begin{tabular}{|l|c|c|c|c|}
\hline Variant of the experiment & $\mathbf{4 0 ~} \mathbf{~ m g} / \mathbf{k g}$ & $\begin{array}{c}\mathbf{4 0} \mathbf{~ m g} / \mathbf{k g}+\text { diatomite } \\
\text { pretreated with } \\
\mathbf{F e}^{3+}+\text { blue clay }\end{array}$ & $\begin{array}{c}\mathbf{4 0 ~} \mathbf{~ m g} / \mathbf{k g}+ \\
\text { sapropel+CaCO }\end{array}$ & $\mathbf{H C P}_{\mathbf{0 5}}$ \\
\hline $\begin{array}{l}\text { Arsenic content in plant } \\
\text { (mean value), } \mathrm{mg} / \mathrm{kg}\end{array}$ & 12,0 & 1,7 & 7,4 & 4,22 \\
\hline $\begin{array}{l}\text { Arsenic content in grain, } \\
\mathrm{mg} / \mathrm{kg}\end{array}$ & 0,3 & 0,01 & 0,1 & 0,06 \\
\hline
\end{tabular}

Variants of the field experiment were the following: sorbing material application; checking (without sorbing material application). The developed sorbing material application provided arsenic content decrease in plant (mean value) - in 5,3 times; in oat grain - in 6,5 times. Grain crop met the requirements of the Sanitary standard 42-123-408986 (Table. 2). After sorbing material application mobile arsenic content in soil was lower in 2,3 times as compared to the checking plots.

Thus application of diatomite pretreated with $\mathrm{Fe}^{3+}+$ blue clay provides to obtain high quality grain crop in the polluted soils.

Additional soil analysis showed that the developed sorbing material didn't deteriorate agrochemical properties of soil (content of phosphates, $\mathrm{Fe}, \mathrm{pH}$ ) which is very important at detoxication of soil so long as qualitative characteristics being at the previous level.

Tentative mechanism of mobile arsenic sorbing on the developed sorbing material can be described as the following:

At sorbing material application insoluble iron arsenate is formed.

$\mathrm{Fe}^{3+}+\mathrm{AsO}_{4}^{3-}=\mathrm{FeAsO}_{4}$

$\mathrm{Fe}^{3+}+\mathrm{AsO}_{3}^{-}=\mathrm{Fe}\left(\mathrm{AsO}_{3}\right)_{3}$

Table 2

Arsenic content in oat, coefficient of biological magnification, mobile arsenic content in soil

\begin{tabular}{|c|c|c|c|}
\hline $\begin{array}{l}\text { Variant of the field } \\
\text { experiment }\end{array}$ & $\begin{array}{c}\text { Checking } \\
\text { (initial As content } 54,5 \mathrm{mg} / \mathrm{kg} \text { ) }\end{array}$ & $\begin{array}{l}\text { initial As content } 54,5 \mathrm{mg} / \mathrm{kg}+ \\
\text { diatomite pretreated with } \mathrm{Fe}^{3+}+\text { blue } \\
\text { clay }\end{array}$ & $\mathrm{HCP}_{05}$ \\
\hline \multicolumn{4}{|c|}{ Arsenic content in oat, $\mathrm{mg} / \mathrm{kg}$} \\
\hline in plant (mean value) & 6,9 & 1,3 & 3,35 \\
\hline in grain & 3,1 & 0,18 & 0,27 \\
\hline \multicolumn{3}{|c|}{ Coefficient of biological magnification } & \\
\hline in plant (mean value) & 0,6 & 0,22 & \\
\hline in grain & 0,47 & 0,2 & \\
\hline \multicolumn{4}{|c|}{ Content of mobile arsenic in soil, for the end of the vegetation, $\mathrm{mg} / \mathrm{kg}$} \\
\hline Content of mobile arsenic & 0,3 & 0,1 & 0,08 \\
\hline
\end{tabular}

As the result of hydrolysis in the water solution arsenic turns into soluble compound again.

$\mathrm{FeAsO}_{4}+\mathrm{H}_{2} \mathrm{O}=\mathrm{FeOH}^{2+}+\mathrm{H}++\mathrm{AsO}_{4}^{3-}$

$\mathrm{Fe}\left(\mathrm{AsO}_{3}\right)_{3}+\mathrm{H}_{2} \mathrm{O}=3 \mathrm{FeOH}^{2+}+\mathrm{H}^{+}+\mathrm{AsO}_{3}$ 
$\mathrm{Al}^{3+}$ being contained in blue clay provides the same effect.

$\mathrm{Al}^{3+}+\mathrm{AsO}_{4}^{3-}=\mathrm{AlAsO}_{4}$

$\mathrm{Al}^{3+}+\mathrm{AsO}_{3}^{-}=\mathrm{Al}\left(\mathrm{AsO}_{3}\right)_{3}$

Anionic form of arsenic is easily reduced to cationic form.

$\mathrm{AsO}_{3}^{-}+\mathrm{H}^{+}+\mathrm{e}$ (electrons of the organic compounds) $=\mathrm{H}_{2} \mathrm{O}+\mathrm{As}^{3+}$

Ferric iron is reduced to the ferrous iron preventing arsenic reduction.

$\mathrm{Fe}^{3+}+\mathrm{e}$ (electrons of the organic compounds) $=\mathrm{Fe}^{2+}$

$2 \mathrm{Fe}^{3+}+\mathrm{As}^{3+}+3 \mathrm{H}_{2} \mathrm{O}=2 \mathrm{Fe}^{2+}+\mathrm{AsO}_{3}^{-}+6 \mathrm{H}^{+}$

Composition on the base of diatomite and blue clay contains both sorbing materials for sorption of anionic form of arsenic and oxidizing agents hindering arsenic reduction.

Thus the developed composition (diatomite pretreated with $\mathrm{Fe}^{3+}+$ blue clay) for detoxication of soils polluted with arsenic provides to obtain ecologically standard crop in the highly polluted soils, quality of crops and agrochemical properties of soil are not deteriorated.

\section{References}

[1]. Natural mineral sorbing materials. Kiev, Academy of science of Ukrain, 1960 - 371 p. (in Russian).

[2]. Kireycheva L.V., Moskovkina L.I. Reclamation of soils polluted with arsenic// Plodorodiye. - 2011. - № 4. - p. 51-52. (in Russian).

[3]. Kireycheva L.V., Moskovkina L.I. Detoxication of soil polluted with arsenic using natural sorbing materials // Present day issues of reclamation and water economy. V 1. - M. - 2009. - p. 81-88. (in Russian). 